\title{
Epstein-Barr virus latent membrane protein 1 induces CD69 expression through activation of nuclear factor- $\mathrm{\kappa B}$
}

\author{
CHIE ISHIKAWA $^{1,2}$ and NAOKI MORI ${ }^{1}$ \\ ${ }^{1}$ Department of Microbiology and Oncology, Graduate School of Medicine, University of the Ryukyus, Nishihara, \\ Okinawa 903-0215; ${ }^{2}$ Transdisciplinary Research Organization for Subtropics and Island Studies, \\ Nishihara, Okinawa 903-0213, Japan
}

Received January 10, 2013; Accepted February 25, 2013

DOI: 10.3892/ijo.2013.1871

\begin{abstract}
Latent membrane protein-1 (LMP-1) of Epstein-Barr virus (EBV) promotes tumorigenesis. Here, we report that LMP-1 activates the immunoregulatory molecule CD69 gene transcription through a nuclear factor- $\mathrm{\kappa B}(\mathrm{NF}-\kappa \mathrm{B})$-dependent pathway. CD69 expression was upregulated in LMP-1-expressing EBV-immortalized human B-cell lines and an EBV-positive Burkitt's lymphoma cell line. LMP-1 expression increased CD69 expression at the transcriptional level. CD69 promoter was regulated by LMP-1 activation of NF- $\kappa$ B via the carboxyterminal activation region 1 and 2. Promoter deletion analysis indicated that two NF- $\mathrm{kB}$ binding sites are necessary for activation of the CD69 promoter. Electrophoretic mobility shift analysis demonstrated that LMP-1 activates both NF- $\mathrm{BB}$ binding sites in the CD69 promoter. This is the first report of the regulation of CD69 expression by LMP-1, and this novel finding may, thus, represent an important link between the EBV oncoprotein LMP-1 and its critical role in the development of EBV-associated diseases.
\end{abstract}

\section{Introduction}

Epstein-Barr virus (EBV) is a ubiquitous human $\gamma$-herpesvirus and was one of the first human virus linked to cancer (1). EBV can infect, transform and immortalize B-lymphocytes in vitro, giving rise to lymphoblastoid cell lines (LCLs), which display elevated levels of several cellular activation antigens (2). Consistent with this feature, persistent, latent EBV infection is

Correspondence to: Professor Naoki Mori, Department of Microbiology and Oncology, Graduate School of Medicine, University of the Ryukyus, 207 Uehara, Nishihara, Okinawa 903-0215, Japan E-mail: naokimori50@gmail.com

Dr Chie Ishikawa, Transdisciplinary Research Organization for Subtropics and Island Studies, 1 Senbaru, Nishihara, Okinawa 903-0213, Japan

E-mail: chiezo@lab.u-ryukyu.ac.jp

Key words: CD69, Epstein-Barr virus, latent membrane protein 1, nuclear factor- $\mathrm{\kappa B}$, carboxy-terminal activation region present in several lymphoid malignancies including Burkitt's lymphoma (BL) (3).

EBV latent membrane protein-1 (LMP-1) is a key effector in EBV-mediated transformation of B cells (4). It consists of 386 amino acids and its carboxy-terminal cytoplasmic domain contains two carboxy-terminal activation regions (CTARs), CTAR-1 and CTAR-2. CTAR-1 and CTAR-2 are known to activate the nuclear factor- $\mathrm{KB}(\mathrm{NF}-\kappa \mathrm{B})$ signaling pathway (5-8). NF- $\kappa \mathrm{B}$ is inactive in the cytosol because it is bound to $\operatorname{I\kappa B} \alpha$ and $\operatorname{I\kappa B} \beta$, and becomes active after phosphorylation and subsequent degradation of $I \kappa \mathrm{B} \alpha$ and IкB $\beta$ (9). The released NF- $\kappa B$ from the complex translocates to the nucleus where it activates a variety of genes (9). The high-molecular weight complex, IкB kinase (IKK), which is composed of two catalytic subunits, IKK $\alpha$ and IKK $\beta$, and a regulatory subunit, IKK $\gamma$, phosphorylates IKBs (9). Members of the p38 mitogen-activated protein kinase (MAPK) kinase kinase protein kinase family mediate the physiological activation of IKK (10). These kinases include NF- $\mathrm{BB}$-inducing kinase (NIK) (11) and MAPK/extracellular signal-regulated kinase kinase 1 (12). CTAR-1 binds to tumor necrosis factor receptor-associated factors (TRAFs) (5), whereas CTAR-2 binds to the tumor necrosis factor receptor-associated death domain (TRADD) (6). NF- $\mathrm{kB}$ activation by the CTAR-1 and CTAR-2 domains of LMP-1 is likely to be mediated by the binding of TRAFs directly or indirectly to both the CTAR-1 and CTAR-2 domains (5-8). NF- $\kappa$ B activation by LMP-1 is mediated by NIK or a related MAPK kinase kinase, and subsequent activation of the IKK complex $(7,13)$. NIK is activated by aggregated TRAF2 (13). Thus, binding of LMP-1 to TRAFs and TRADD initiates the formation of a signaling complex that leads to activation of NF- $\mathrm{KB}$ and MAPK (5-8), resulting in upregulation of several genes expression.

The human activation inducer molecule CD69 is a disulfide-linked transmembrane homodimeric glycoprotein (14). CD69 is not detected in peripheral blood lymphocytes, but it is expressed by small subsets of $\mathrm{T}$ and $\mathrm{B}$ cells in peripheral lymphoid tissues $(15,16)$. CD69 acts as a signal transducer in inflammatory processes. Recent studies have established the role of CD69 as an intrinsic negative modulator of T cell responses (17). In the present report, we show that CD69 is a transcriptional target of LMP-1 activation of NF- $\mathrm{KB}$ via CTAR-1 and CTAR-2. 


\section{Materials and methods}

Cell lines. Raji is a human EBV-positive BL cell line, and LCL-Ao, LCL-Ka and LCL-Ku are EBV-immortalized human B-cell lines generated from peripheral blood mononuclear cells of healthy volunteers. These lymphoid cell lines were cultured in Roswell Park Memorial Institute (RPMI)-1640 medium supplemented with 10 or $20 \%$ heat-inactivated fetal bovine serum, $50 \mathrm{U} / \mathrm{ml}$ penicillin and $50 \mu \mathrm{g} / \mathrm{ml}$ streptomycin. Human embryonic kidney 293T cells were maintained in Dulbecco's modified Eagle's medium supplemented with $10 \%$ heat-inactivated fetal bovine serum, $50 \mathrm{U} / \mathrm{ml}$ penicillin and $50 \mu \mathrm{g} / \mathrm{ml}$ streptomycin.

Flow cytometry. The expression of CD69 was analyzed by flow cytometry with phycoerythrin (PE)-labeled mouse monoclonal antibody against CD69 (clone TP1.55.3; Beckman Coulter, Fullerton, CA). Analyses were carried out with isotype-matched control antibody. The cells were incubated with the antibody for $30 \mathrm{~min}$, washed with cell WASH (Becton-Dickinson Immunocytometry Systems, San Jose, CA) and then subjected to analysis in the cytometer.

RNA detection. Total RNA was prepared from various cell cultures by TRIzol (Invitrogen, Carlsbad, CA) according to the protocol provided by the manufacturer. First-strand cDNA was synthesized from $1 \mu \mathrm{g}$ total cellular RNA using a PrimeScript RT-PCR kit (Takara Bio Inc., Otsu, Japan) with random primers. The primers used were 5'-CATAGCTCTCATTGCCTTA TCAGT-3' (forward) and 5'-CCTCTCTACCTGCGTATC GTTT-3' (reverse) for CD69, 5'-GTGACTGGACTGGAGG AGCC-3' (forward) and 5'-GAGGGAGTCATCGTGGT GGTG-3' (reverse) for LMP-1, and 5'-GTGGGGCGCCCCAG GCACCA-3' (forward) and 5'-CTCCTTAATGTCACGCACG ATTTC-3' (reverse) for $\beta$-actin. The length of the semiquantitative reverse transcription-PCR (RT-PCR) for each gene was: 30 cycles for CD69 and LMP-1, and 28 cycles for $\beta$-actin. The PCR products were fractionated on $2 \%$ agarose gels and visualized by ethidium bromide staining.

Plasmids and transfections. Luciferase assay was performed to confirm that LMP-1 induces the CD69 promoter activation. Approximately $3 \times 10^{5} 293 \mathrm{~T}$ cells per plate were transfected by the calcium phosphate DNA co-precipitation method. All transfections included appropriate reporter and effector plasmids. The expression plasmids pSG5-LMP-1, pSG5-LMP-1 $\Delta 187-351$, pSG5-LMP-1 $\Delta 349$ and pSG5LMP-1 $\Delta$ 194-386 were kindly provided by Dr Martin Rowe (University of Wales College of Medicine, Cardiff, UK) $(18,19)$. The CD69 promoter-luciferase gene constructs have already been described $(20,21)$. The single and combined internal deletion mutants of NF- $\mathrm{\kappa B}$ sites were constructed by deletion of the NF- $\mathrm{NB}$ sites of the plasmid pAIM 255-LUC.

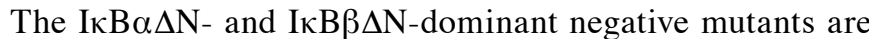
$\mathrm{I} \kappa \mathrm{B} \alpha$ and I $\mathrm{I} \mathrm{B} \beta$ deletion mutants lacking the amino-terminal 36 and 23 amino acids, respectively $(22,23)$. The dominant negative mutants of IKK $\alpha$, IKK $\alpha$ (K44M), IKK $\beta$, IKK $\beta$ (K44A), IKK $\gamma$, IKK $\gamma$ (1-305) and NIK, NIK (KK429/430AA) have been described previously $(24,25)$. Plasmids for truncated TRAF2 and TRAF5 proteins retaining only the TRAF domain, $\triangle T R A F 2$ and $\triangle T R A F 5$, have been described previ- ously $(26,27)$. In all cases, the reference plasmid phRL-TK, which contains the Renilla luciferase gene under the control of the herpes simplex virus thymidine kinase promoter, was cotransfected to correct for transfection efficiency. After $24 \mathrm{~h}$, the transfected cells were collected by centrifugation, washed with phosphate-buffered saline and lysed in reporter lysis buffer (Promega, Madison, WI). Luciferase assays were conducted using the dual luciferase reporter system (Promega), in which the relative luciferase activity was calculated by normalizing transfection efficiency according to the Renilla luciferase activities.

Preparation of nuclear extracts and electrophoretic mobility shift assay (EMSA). Nuclear proteins were extracted as described by Antalis and Godbolt (28) with some modifications, and NF- $\kappa \mathrm{B}$ binding activity to the NF- $\kappa \mathrm{B}$ element was examined by EMSA. Briefly, $5 \mu \mathrm{g}$ of nuclear extracts were preincubated in a binding buffer containing $1 \mu \mathrm{g}$ polydeoxyinosinic-deoxycytidylic acid (GE Healthcare Biosciences, Buckinghamshire, UK), followed by the addition of ${ }^{32} \mathrm{P}$-labeled oligonucleotide probes containing the NF- $\kappa B$ element. The mixtures were incubated for $15 \mathrm{~min}$ at room temperature. The DNA protein complexes were separated on $4 \%$ polyacrylamide gels and visualized by autoradiography. The probes and competitors used were prepared by annealing the sense and antisense synthetic oligonucleotides as follows: the NF- $\kappa$ B element $(\kappa \mathrm{B} 1)$ of the CD69 gene (5'-GATCC AGACAACAGGGAAAACCCATACTTC- 3 '); the NF- $\kappa$ B element ( $(\mathrm{BB} 2)$ of the CD69 gene (5'-GATCCAGAGTCTGGG AAAATCCCACTTTCC-3'); a typical NF- $\kappa B$ element from the IL-2 receptor $\alpha$ chain (IL-2R $\alpha$ ) gene (5'-GATCCGGCAG GGGAATCTCCCTCTC-3') and an AP-1 element of the IL-8 gene (5'-GATCGTGATGACTCAGGTT-3'). The above underlined sequences represent the NF- $\kappa \mathrm{B}$ and AP-1 binding sites, respectively.

\section{Results}

Upregulated CD69 expression in EBV-immortalized human $B$-cell lines and EBV-positive BL cell line. We examined first whether CD69 upregulation is a general feature of EBV-infected B cells. All EBV-immortalized B-cell lines, LCL-Ao, LCL-Ka and LCL-Ku, and EBV-positive BL cell line, Raji, constitutively expressed CD69 on the cell surface (Fig. 1A). In contrast, CD69 was hardly expressed on normal peripheral blood mononuclear cells (data not shown).

LMP-1 upregulates CD69 mRNA and protein expression. EBV-immortalized B-cell lines and Raji cells constitutively express LMP-1 (29,30). Therefore, we analyzed the induction of CD69 expression by LMP-1. Transient expression assays using a mammalian expression vector for LMP-1 were performed in 293T cells. In 293T cells transfected with empty vector (pSG5), CD69 mRNA was not detectable as determined by RT-PCR analysis (Fig. 1B). In contrast, ectopic expression of LMP-1 induced the expression of CD69 mRNA in 293T cells. Next, we investigated whether LMP-1 also transcribed the endogenous CD69 gene. The expression of CD69 antigen on the cell surface of $293 \mathrm{~T}$ cells increased after ectopic expression of LMP-1 in 293T cells, and such increase was time-dependent (Fig. 1C). 

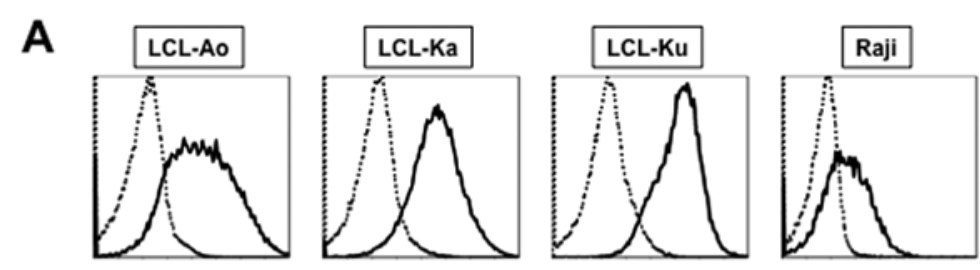

B
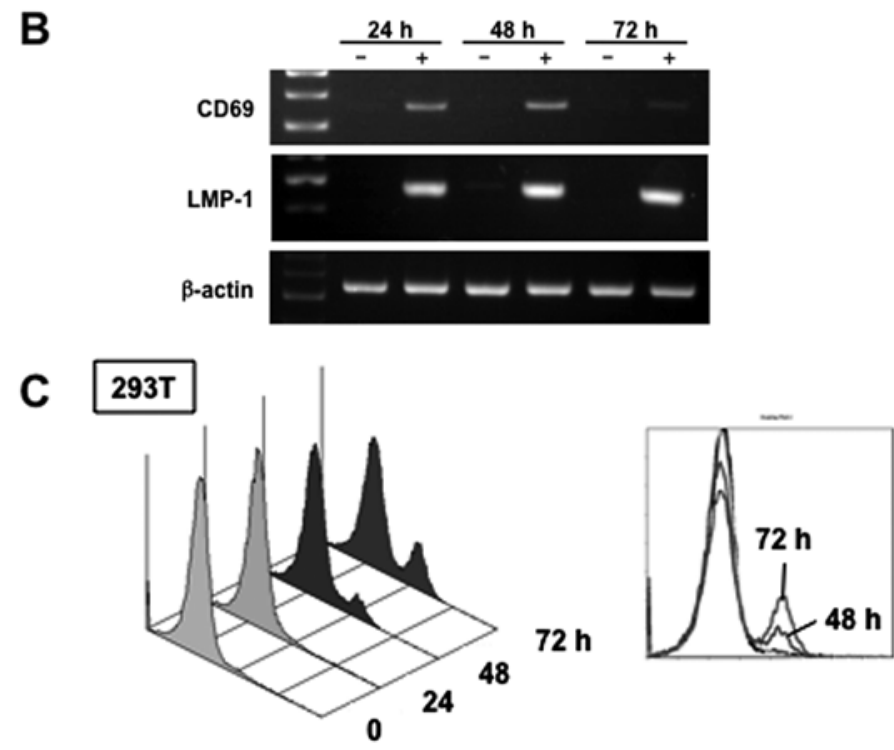

Figure 1.LMP-1 induces CD69 expression. (A) Expression of CD69 on the cell surface of EBV-infected B cells. Flow cytometry of the indicated cell lines. Cells were either stained with an anti-CD69-PE antibody or an isotype control-PE antibody, and subjected to flow cytometry. (B) Ectopic expression of LMP-1 in 293T cells upregulates CD69 mRNA expression. 293T cells were transfected with plasmid encoding LMP-1 or empty vector. Total RNA was isolated from 293T cells at the indicated times, and RT-PCR was carried out for CD69, LMP-1 and $\beta$-actin (loading control). (C) Endogenous CD69 antigen expression on 293T cells after ectopic expression of LMP-1 for 24, 48 and $72 \mathrm{~h}$. The right panel shows an overlay histogram of flow cytometry data.

LMP-1 activates CD69 promoter. To determine whether LMP-1 regulates CD69 promoter activity, transient expression assays using the reporter plasmid pAIM 1.4-LUC and either an expression vector for LMP-1 or empty vector (pSG5) were performed in 293T cells. LMP-1 induced relative levels of CD69 promoterdirected luciferase expression in a dose-dependent manner, suggesting that LMP-1 functionally activates CD69 promoter (Fig. 2A). To map the region in the LMP-1 protein that mediates activation of CD69 promoter, LMP-1 mutants were expressed in 293T cells and their effect on CD69 promoter activity was investigated. The LMP-1 mutants used included LMP-1 $1 \Delta 187$ 351 (which contains only CTAR-2 in the carboxy-terminus), LMP-1 $\Delta 349$ (which lacks CTAR-2), and LMP-1 $\Delta 194-386$ (in which the entire carboxy-terminal cytoplasmic region is deleted) (Fig. 2B, left panel). In cells that expressed LMP-1 $\Delta 194-386$, CD69 promoter activity was not significantly increased (Fig. 2B, right panel). In contrast, LMP-1 $\Delta 187-351$ induced $50 \%$ of wild-type LMP-1 CD69 promoter activation. Furthermore, LMP-1 1349 showed substantial impairment of CD69 promoter activation. These results suggest that LMP-1 activates CD69 expression via the cooperative activity of CTAR-1 and CTAR-2 signaling motifs.

LMP-1 activates the CD69 promoter via the $N F-\kappa B$ signaling pathway. CTAR-1 and CTAR-2 are known to activate the NF- $\mathrm{kB}$ signaling pathway (5-8). Based on the discussed background, we tested the ability of the dominant interfering mutants of IкB $\alpha$,
IкB $\beta$, IKK $\gamma$, TRF2 and TRAF5, and kinase-deficient mutants of IKK $\alpha$, IKK $\beta$ and NIK to inhibit LMP-1-mediated transactivation of CD69-driven reporter gene activity. Expression of each of these inhibitory mutants inhibited LMP-1-induced activation of CD69 promoter (Fig. 2C). These results demonstrated that the signaling components, TRAFs, NIK and IKKs, which are involved in the activation of NF- $\mathrm{kB}$, are also necessary for LMP-1 transactivation of the CD69 promoter.

$L M P-1$ activates the CD69 promoter through two $N F-\kappa B$ sites. The CD69 promoter contains three putative binding sites for NF- $\kappa$ B [positions $-373(\kappa \mathrm{B} 3),-223(\kappa \mathrm{B} 2)$ and $-160(\kappa \mathrm{B} 1)$ ], a putative binding site for early growth response (EGR) at -69 , a composite binding site for Sp1 and EGR at -56, a cyclic adenosine 3',5'-monophosphate response element-binding protein (CREB) binding site at -46 , and two putative AP-1 binding sites at -16 and +1 (Fig. 3A) (20). To study the role of NF- $\mathrm{kB}$ sites in the transcriptional induction of CD69 gene by LMP-1, we transfected 293 T cells with several 5 '-deletion fragments extending from position $-1.4 \mathrm{k}$ to -78 (Fig. 3A), and an expression vector for LMP-1. Progressive removal of 5 -sequence up to position -255 did not significantly inhibit the induced promoter activity, suggesting that the 271-bp fragment, spanning positions -255 to +16 , contained the LMP-1-responsive elements (Fig. 3A). Further deletion of upstream sequences up to position -170 resulted in significant loss of responsiveness to LMP-1. Additional removal of the 


\section{A}

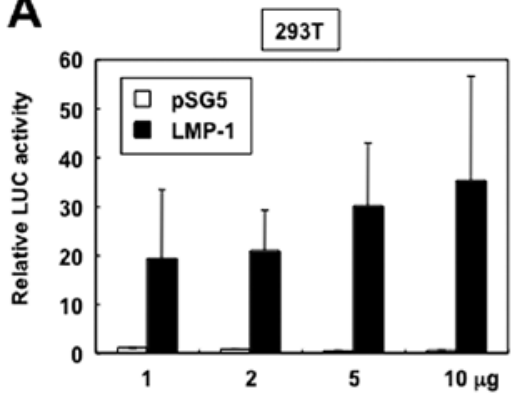

B

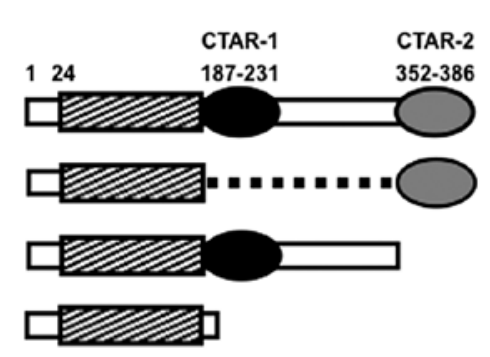

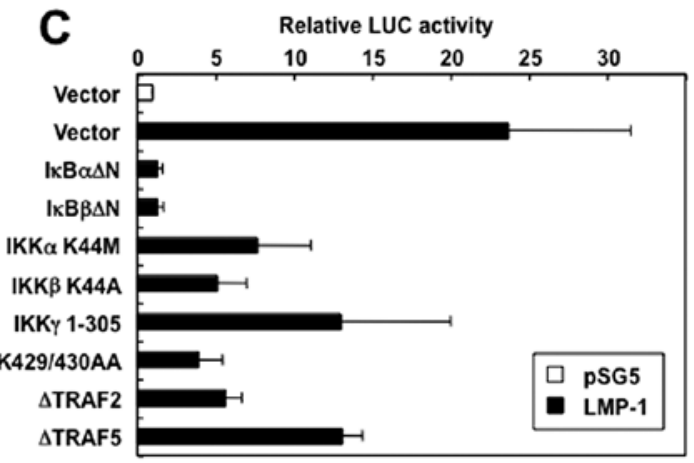

Relative LUC activity

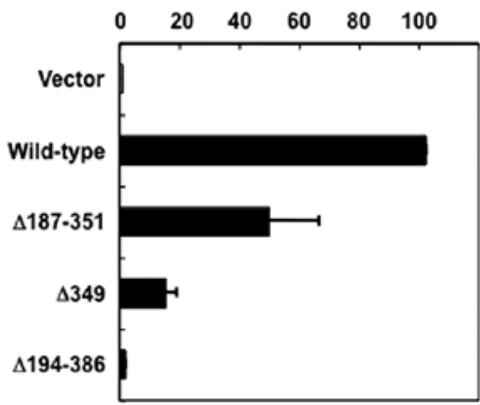

Figure 2. LMP-1 activates the CD69 promoter via the NF-kB signaling pathway. (A) LMP-1 activates the CD69 promoter. 293T cells were transfected with pAIM 1.4-LUC $(0.2 \mathrm{ng})$ together with increasing amounts $(1-10 \mu \mathrm{g})$ of pSG5 or pSG5-LMP-1. Cells were harvested $24 \mathrm{~h}$ post-transfection and luciferase activity was measured with a luminometer. The activities are expressed relative to that of cells transfected with pAIM 1.4-LUC and pSG5, which was defined as 1. (B) Deletions in CTAR-1 and CTAR-2 abrogate the effect of LMP-1 on CD69 promoter activity. 293T cells were cotransfected with plasmids encoding wild-type LMP-1 or various mutants of LMP-1 (5 $\mu \mathrm{g})$ (left) and with pAIM 1.4-LUC (20 ng). The results are represented as fold induction by wild-type or mutant LMP-1 relative to the vector alone. (C) Effects of dominant negative mutants on LMP-1-induced CD69 promoter activation in 293T cells. pSG5 or pSG5-LMP-1 (2 $\mu \mathrm{g})$ was cotransfected with pAIM 1.4-LUC $(0.2 \mathrm{ng})$ and the indicated dominant negative mutants or empty vector $(2 \mu \mathrm{g})$. The activities are expressed relative to that of cells transfected with pAIM 1.4-LUC and empty vectors, which was defined as 1. Data are mean \pm SD of three experiments. LUC, luciferase.

A

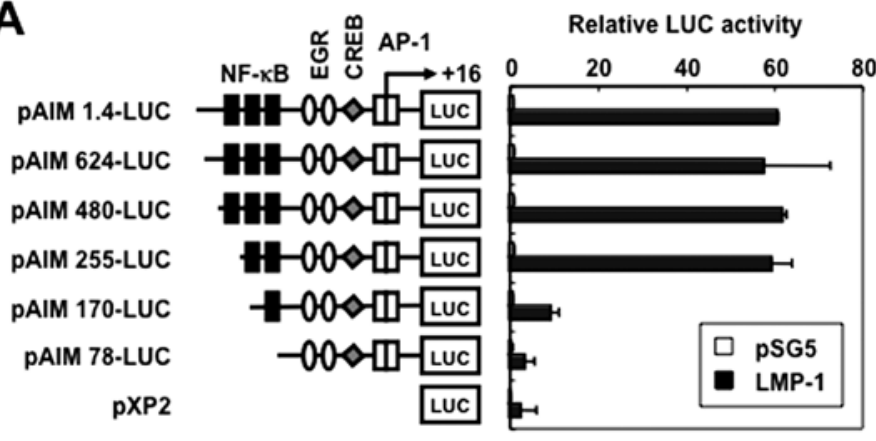

B
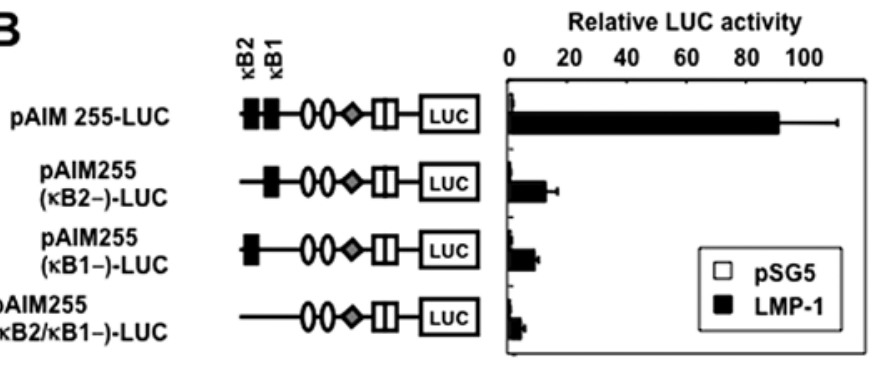

Relative LUC activity

$\begin{array}{llllll}0 & 20 & 40 & 60 & 80 & 100\end{array}$

(KB2/KB1-)-LUC

Figure 3. Two NF- $\kappa$ B sites of the CD69 gene promoter are required for LMP-1-induced CD69 gene transcription. (A) 293T cells were transfected with the indicated CD69 luciferase reporter constructs $(0.2 \mathrm{ng})$ and either empty vector or pSG5-LMP-1 $(5 \mu \mathrm{g})$. The deleted plasmids are indicated on the left side of the figure. The activities are expressed relative to that of cells transfected with pXP2 and an empty vector, which was defined as 1. (B) 293T cells were transfected with pAIM 255-LUC, pAIM 255-LUC with deleted distal NF- $\kappa$ B site [pAIM 255 ( $\kappa$ B2-)-LCU], pAIM 255-LUC with deleted proximal NF- $\kappa$ B site [pAIM 255 ( $\kappa$ B1-)-LUC] or pAIM 255-LUC with double deleted [pAIM 255 ( $\kappa \mathrm{B} 2 / \kappa \mathrm{B} 1-)-\mathrm{LUC}$ ] $(0.2 \mu \mathrm{g})$ together with either empty vector or pSG5-LMP-1 (5 $\mu \mathrm{g})$. Schematic diagrams of the CD69 reporter constructs containing the wild-type (pAIM 255-LUC) and internal deletion mutants of $\kappa \mathrm{B} 1$ and/or $\kappa \mathrm{B} 2 \mathrm{motifs}$ are indicated on the left side of the figure. The activities are expressed relative to that of cells transfected with pAIM 255-LUC and an empty vector, which was defined as 1 . Data are mean \pm SD of three experiments. LUC, luciferase. 


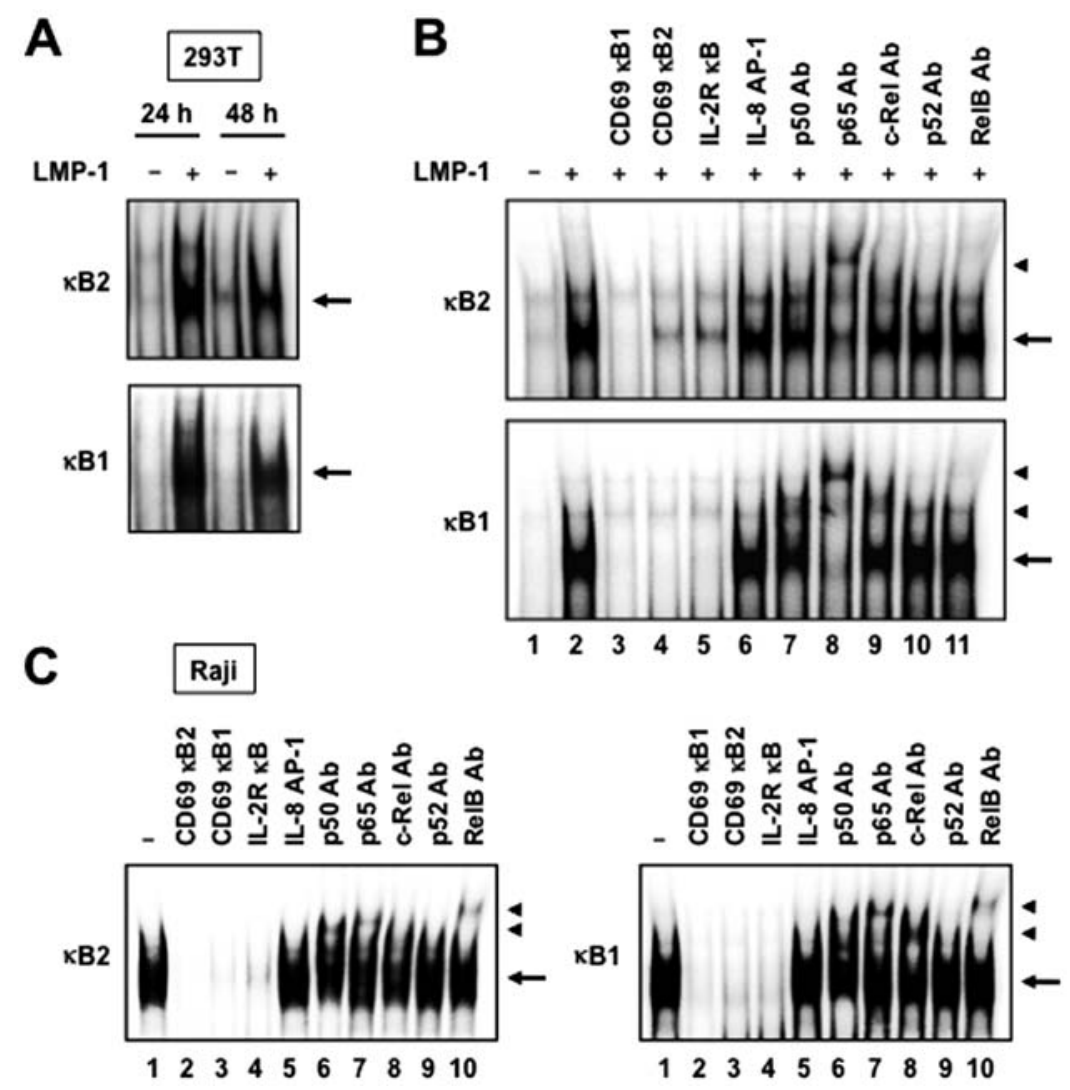

Figure 4. LMP-1 induces NF-кB binding to DNA. (A) 293T cells were transfected with control plasmid or LMP-1 expression plasmid. Nuclear proteins were extracted at the indicated times. The binding of NF- $\mathrm{kB}$ to DNA was measured by EMSA experiments. (B and C) Nuclear extracts from $293 \mathrm{~T}$ cells transfected with (B) control plasmid or LMP-1 expression plasmid or (C) Raji cells were incubated with the labeled double-stranded DNA probes representing the CD69 $\kappa$ B1 and кB2 sites. Nuclear extracts were subjected to competition analysis with an excess of unlabeled double-stranded oligonucleotides representing the CD69 $\mathrm{\kappa B} 1$ and $\kappa \mathrm{B} 2$ sites (lanes 3 and 4 in B and lanes 2 and 3 in C, respectively), a consensus NF- $\mathrm{KB}$ site from the IL-2R $\alpha$ promoter (lane 5 in B and lane 4 in C) or an AP-1 site from the IL-8 promoter (lane 6 in B and lane 5 in C). The indicated unlabeled oligonucleotides were incubated with nuclear extracts for 15 min prior to binding reactions. Nuclear extracts were also subjected to supershift assays with either no antibody (lane 2 in B and lane 1 in C) or the indicated antibodies (Ab) (lanes 7-11 in B and lanes 6-10 in C). The antibodies were incubated with nuclear extracts for $45 \mathrm{~min}$ prior to binding reactions. Arrows, specific complexes; arrowhead, the DNA binding complex supershifted by the antibody. Representative results of three experiments of similar results.

5'-sequences up to position -78 further affected the inducible promoter activity.

Two potential NF- $\mathrm{BB}$-binding sequences were identified at positions $-160(\kappa \mathrm{B} 1)$ and $-223(\kappa \mathrm{B} 2)$ spanning positions -255 to +16 bp. $\kappa \mathrm{B} 1$ and $\kappa \mathrm{B} 2$ were identical to those found in the gene promoters of c-myc and IL-6, respectively (31). To test the relative contribution of the $N F-\kappa B$ binding sites to the LMP-1-mediated activation of CD69, plasmids with internal deletion mutants of these sites in the CD69 promoter were transfected (Fig. 3B). Single deletion of the $\kappa \mathrm{B} 1$ or $\kappa \mathrm{B} 2$ site resulted in reduction of the inducible activity. Double deletions of the $\kappa \mathrm{B} 1$ and $\kappa \mathrm{B} 2$ sites further reduced Tax-mediated activation of this reporter construct. These results indicate that the two NF- $\kappa \mathrm{B}$ binding sites in the CD69 promoter regulate LMP-1-induced upregulation of CD69.

LMP-1 induces $N F-\kappa B$ binding to DNA. Since both NF- $\mathrm{BB}$ binding sites of the CD69 promoter are required for LMP-1-mediated CD69 gene transcription, we studied the ability of LMP-1 to activate NF- $\kappa$ B binding to DNA. For this purpose, 293T cells were transfected with control plasmid (empty vector) or LMP-1 expression plasmid for 24 or $48 \mathrm{~h}$, followed by extraction of nuclear proteins. EMSA demonstrated that LMP-1 increased the binding of $\mathrm{NF}-\kappa \mathrm{B}$ to ${ }^{32} \mathrm{P}$-labeled oligonucleotides representing the $\kappa \mathrm{B} 1$ and $\kappa \mathrm{B} 2$ sites (Fig. 4A). The specificity of DNA-protein complex formation was determined by competition studies with unlabeled competitors. As expected, excess of cold CD69 $\kappa \mathrm{B} 1$ or $\kappa \mathrm{B} 2$ double-stranded oligonucleotide, or consensus $\mathrm{NF}-\kappa \mathrm{B}$ site from the IL-2R $\alpha$ promoter, effectively competed with the labeled probes and eliminated the binding of nuclear extracts from 293T cells transfected with LMP-1 expression plasmid (Fig. 4B, lanes 2-5). In contrast, the unlabeled IL-8 AP-1 element did not compete with labeled probes (Fig. 4B, lanes 2 and 6). The nucleoproteins binding to both $\mathrm{NF}-\kappa \mathrm{B}$ sites were composed of p50, p65 and c-Rel subunits of the NF- $\kappa \mathrm{B}$ family, as demonstrated by supershift experiments with specific antibodies (Fig. 4B, lanes 7-9).

Finally, to determine the role of LMP-1 on endogenous $\mathrm{NF}-\kappa \mathrm{B}$ binding to DNA, we measured NF- $\kappa \mathrm{B}$ binding to respective NF- $\kappa \mathrm{B}$ elements in the CD69 promoter in LMP-1- and CD69-expressing Raji cells. As expected, protein complexes bound to both $\kappa \mathrm{B} 1$ and $\kappa \mathrm{B} 2$ sites were detected in nuclear extracts from Raji cells (Fig. 4C, lane 1). The specificity of DNA-protein complexes in these extracts was determined by competition studies using unlabeled competitors. As observed in nuclear extracts from 293 T cells transfected with LMP-1 
expression plasmid, cold $\kappa \mathrm{B} 1$ and $\kappa \mathrm{B} 2$ oligonucleotides, and consensus NF- $\kappa \mathrm{B}$ site from the IL-2R $\alpha$ promoter, but not the IL-8 AP-1 element, efficiently competed with labeled probes (Fig. 4C, lanes 1-5). Antibodies against p50, p65, c-Rel and RelB induced a supershift of the DNA-protein complexes (Fig. 4C, lanes 6-8 and 10). Taken together, the results indicate that $\mathrm{NF}-\kappa \mathrm{B}$ proteins bind to both $\kappa \mathrm{B}$ elements of the CD69 promoter in LMP-1- and CD69-expressing Raji cells.

\section{Discussion}

The main issue addressed in this study was whether LMP-1 induces CD69 gene transcription and the possible mechanisms underlying this activity. In this study, we showed that EBV LMP-1 activates CD69 gene transcription through an NF-кBdependent pathway. The activation of CD69 promoter was mediated cooperatively by CTAR-1 and CTAR-2 of LMP-1, as demonstrated by ectopic expression of LMP-1 mutants. Interestingly, previous studies have demonstrated that CTAR-1 and CTAR-2 cooperatively activate the NF- $\kappa$ B signaling pathway (5-8), and that CD69 promoter harbors three $\kappa \mathrm{B}$ consensus sites ( $\kappa \mathrm{B} 1-\kappa \mathrm{B} 3$ ) (20). The results also showed that both $\kappa \mathrm{B} 1$ and $\kappa \mathrm{B} 2$ domains of the CD69 promoter were absolutely necessary for LMP-1-induced transcription.

The present results indicate that LMP-1 induces CD69 promoter activation through NIK-, IKK $\alpha$ - and IKK $\beta$ kinasedependent pathways. Dominant negative forms of NIK, IKK $\alpha$, IKK $\beta$ - and IKK $\gamma$ inhibited LMP-1-induced CD69 promoter activation. These results are consistent with previous evidence that NIK and IKKs are implicated in the pathways through which LMP-1 induces NF- $\mathrm{B}$ activation $(7,13)$. LMP-1 CTAR-1 directly recruits TRAF1, 2, 3 and 5 whereas CTAR-2 indirectly recruits TRAF2 and 6 (5-8). CTAR-1 activates TRAF2-, NIKand IKK $\alpha$-mediated NF- $\kappa$ B pathways, and CTAR-2 activates TRAF6-, IKK $\alpha$-, IKK $\beta$ - and IKK $\gamma$-mediated NF- $\kappa$ B pathways (7). Overexpression of dominant negative forms of TRAF2 and TRAF5 inhibited LMP-1-mediated CD69 promoter activation, indicating that NF- $\mathrm{KB}$ is an important component of LMP-1mediated CD69 gene induction from TRAFs-interacting sites.

CD69 has been found to be rapidly upregulated on all the leukocyte lineages studied, upon activation with the corresponding stimuli (14). CD69 expression has also been reported in infections (32-35). Earlier studies showed that CD69 regulates the immune response by modulating the expression of various cytokines. CD69-deficient mice show increased antitumor and autoimmune responses, which are caused at least in part by increased production of proinflammatory cytokines and chemokines $(36,37)$. More recently, tumor-derived CD69 ${ }^{+}$ $\mathrm{T}$ cells have been found to induce immune tolerance in the tumor environment (38). CD69 is reported to be a critical negative regulator of immune activation during intracellular bacterial infection (35). LMP-1-mediated CD69 may have an important role in the immune surveillance evasion by EBV-infected cells.

In summary, our experiments indicate that LMP-1 CTAR-1 and -2 can regulate $\mathrm{CD} 69$ gene at the transcriptional level via two NF- $\kappa$ B-binding sites in its promoter, and TRAFs, NIK and IKKs are effectors of CD69 promoter activation from LMP-1. Further studies are necessary to resolve the question of the role of CD69 in EBV-associated diseases.

\section{Acknowledgements}

We thank Dr Martin Rowe, Dr Francisco Sánchez-Madrid, Dr Dean W. Ballard, Dr Romas Geleziunas, Dr Kuan-Teh Jeang, Dr Marta Muzio and Dr Toshiki Watanabe, for providing the expression vectors for LMP-1 and its mutants; CD69 promoter pXP2 luciferase reporter plasmids; expression vectors for I $\mathrm{B} \alpha$ and $\mathrm{I} \kappa \mathrm{B} \beta$-dominant negative mutants; for NIK-, IKK $\alpha$ - and IKK $\beta$-dominant negative mutants; for IKK $\gamma$-dominant negative mutant; and for plasmids for truncated TRAF2 and TRAF5. We also thank Dr Zahidunnabi Dewan for providing LCL-Ao, LCL-Ka and LCL-Ku.

\section{References}

1. Epstein MA, Achong BG and Barr YM: Virus particles in cultured lymphoblasts from Burkitt's lymphoma. Lancet 1: 702-703, 1964.

2. Kieff ED and Rickinson AB: Epstein-Barr virus and its replication. In: Fields' virology. Knipe DM and Howley PM (eds.) Lippincott Williams \& Wilkins, Philadelphia, pp2603-2654, 2006.

3. Taylor GS and Blackbourn DJ: Infectious agents in human cancers: lessons in immunity and immunomodulation from gammaherpesviruses EBV and KSHV. Cancer Lett 305: 263-278, 2011.

4. Kaye KM, Izumi KM and Kieff E: Epstein-Barr virus latent membrane protein 1 is essential for B-lymphocyte growth transformation. Proc Natl Acad Sci USA 90: 9150-9154, 1993.

5. Devergne O, Cahir McFarland ED, Mosialos G, Izumi KM, Ware CF and Kieff E: Role of the TRAF binding site and $\mathrm{NF}-\kappa \mathrm{B}$ activation in Epstein-Barr virus latent membrane protein 1-induced cell gene expression. J Virol 72: 7900-7908, 1998.

6. Izumi KM and Kieff ED: The Epstein-Barr virus oncogene product latent membrane protein 1 engages the tumor necrosis factor receptor-associated death domain protein to mediate B lymphocyte growth transformation and activate NF- $\kappa \mathrm{B}$. Proc Natl Acad Sci USA 94: 12592-12597, 1997.

7. Soni V, Cahir-McFarland E and Kieff E: LMP1 TRAFficking activates growth and survival pathways. Adv Exp Med Biol 597: 173-187, 2007.

8. Schultheiss U, Püschner S, Kremmer E, Mak TW, Engelmann H, Hammerschmidt W and Kieser A: TRAF6 is a critical mediator of signal transduction by the viral oncogene latent membrane protein 1. EMBO J 20: 5678-5691, 2001.

9. Hayden MS and Ghosh S: Shared principles in NF-kB signaling. Cell 132: 344-362, 2008.

10. Zandi E and Karin M: Bridging the gap: composition, regulation, and physiological function of the IкB kinase complex. Mol Cell Biol 19: 4547-4551, 1999.

11. Woronicz JD, Gao X, Cao Z, Rothe M and Goeddel DV: IкB kinase $-\beta$ : NF- $\kappa$ B activation and complex formation with $\mathrm{I} \kappa \mathrm{B}$ kinase- $\alpha$ and NIK. Science 278: 866-869, 1997.

12. Lee FS, Peters RT, Dang LC and Maniatis T: MEKK1 activates

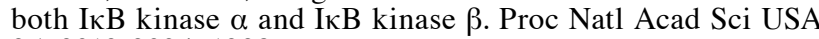
95: 9319-9324, 1998.

13. Sylla BS, Hung SC, Davidson DM, Hatzivassiliou E, Malinin NL, Wallach D, Gilmore TD, Kieff E and Mosialos G: Epstein-Barr virus-transforming protein latent infection membrane protein 1 activates transcription factor $N F-\kappa B$ through a pathway that includes the NF- $\mathrm{B}$-inducing kinase and the IкB kinases IKK $\alpha$ and IKK $\beta$. Proc Natl Acad Sci USA 95: 10106-10111, 1998.

14. Sánchez-Mateos P and Sánchez-Madrid F: Structure-function relationship and immunochemical mapping of external and intracellular antigenic sites on the lymphocyte activation inducer molecule, AIM/CD69. Eur J Immunol 21: 2317-2325, 1991.

15. Sant'Angelo DB, Lucas B, Waterbury PG, Cohen B, Brabb T, Goverman J, Germain RN and Janeway CA Jr: A molecular map of T cell development. Immunity 9: 179-186, 1998.

16. Testi R, D'Ambrosio D, De Maria R and Santoni A: The CD69 receptor: a multipurpose cell-surface trigger for hematopoietic cells. Immunol Today 15: 479-483, 1994. 
17. De la Fuente H, Cibrián D and Sánchez-Madrid F: Immunoregulatory molecules are master regulators of inflammation during the immune response. FEBS Lett 586: 2897-2905, 2012.

18. Huen DS, Henderson SA, Croom-Carter D and Rowe M: The Epstein-Barr virus latent membrane protein-1 (LMP1) mediates activation of NF- $\kappa \mathrm{B}$ and cell surface phenotype via two effector regions in its carboxy-terminal cytoplasmic domain. Oncogene 10: 549-560, 1995.

19. Floettmann JE and Rowe M: Epstein-Barr virus latent membrane protein-1 (LMP1) C-terminus activation region 2 (CTAR2) maps to the far C-terminus and requires oligomerisation for NF- $\mathrm{KB}$ activation. Oncogene 15: 1851-1858, 1997.

20. López-Cabrera M, Muñoz E, Blázquez MV, Ursa MA, Santis AG and Sánchez-Madrid F: Transcriptional regulation of the gene encoding the human C-type lectin leukocyte receptor AIM/CD69 and functional characterization of its tumor necrosis factor- $\alpha$-responsive elements. J Biol Chem 270 : 21545-21551, 1995.

21. Castellanos Mdel C, López-Giral S, López-Cabrera M and de Landázuri MO: Multiple cis-acting elements regulate the expression of the early $\mathrm{T}$ cell activation antigen CD69. Eur J Immunol 32: 3108-3117, 2002.

22. Brockman JA, Scherer DC, McKinsey TA, Hall SM, Qi X, Lee WY and Ballard DW: Coupling of a signal response domain in I $\kappa \mathrm{B} \alpha$ to multiple pathways for NF- $\kappa \mathrm{B}$ activation. Mol Cell Biol 15: 2809-2818, 1995.

23. McKinsey TA, Brockman JA, Scherer DC, Al-Murrani SW, Green PL and Ballard DW: Inactivation of $I \kappa B \beta$ by the Tax protein of human T-cell leukemia virus type 1 : a potential mechanism for constitutive induction of NF- $\mathrm{KB}$. Mol Cell Biol 16: 2083-2090, 1996.

24. Geleziunas R, Ferrell S, Lin X, Mu Y, Cunningham ET Jr, Grant M, Connelly MA, Hambor JE, Marcu KB and Greene WC: Human T-cell leukemia virus type 1 Tax induction

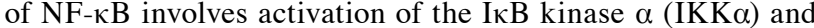
IKK $\beta$ cellular kinases. Mol Cell Biol 18: 5157-5165, 1998.

25. Iha H, Kibler KV, Yedavalli VRK, Peloponese JM, Haller K, Miyazato A, Kasai T and Jeang K-T: Segregation of NF- $\kappa B$ activation through NEMO/IKK $\gamma$ by Tax and TNF $\alpha$ : implications for stimulus-specific interruption of oncogenic signaling. Oncogene 22: 8912-8923, 2003.

26. Muzio M, Ni J, Feng P and Dixit VM: IRAK (Pelle) family member IRAK-2 and MyD88 as proximal mediators of IL-1 signaling. Science 278: 1612-1615, 1997.

27. Aizawa S, Nakano H, Ishida T, Horie R, Nagai M, Ito K, Yagita $\mathrm{H}$, Okumura $\mathrm{K}$, Inoue $\mathrm{J}$ and Watanabe $\mathrm{T}$ : Tumor necrosis factor receptor associated factor (TRAF) 5 and TRAF2 are involved in CD30-mediated NFKB activation. J Biol Chem 272: 2042-2045, 1997.
28. Antalis TM and Godbolt D: Isolation of intact nuclei from hematopoietic cell types. Nucl Acids Res 19: 4301, 1991.

29. Dewan MZ, Tomita M, Katano H, Yamamoto N, Ahmed S, Yamamoto M, Sata T, Mori N and Yamamoto N: An HIV protease inhibitor, ritonavir targets the nuclear factor-kappaB and inhibits the tumor growth and infiltration of EBV-positive lymphoblastoid B cells. Int J Cancer 124: 622-629, 2009.

30. Xu Z-G, Iwatsuki K, Oyama N, Ohtsuka M, Satoh M, Kikuchi S, Akiba $\mathrm{H}$ and Kaneko F: The latency pattern of Epstein-Barr virus infection and viral IL-10 expression in cutaneous natural killer/T-cell lymphomas. Br J Cancer 84: 920-925, 2001.

31. Baeuerle PA: The inducible transcription activator $N F-\kappa B$ : regulation by distinct protein subunits. Biochim Biophys Acta 1072: 63-80, 1991 .

32. Hodge G, Hodge S, Han P and Haslam R: Multiple leucocyte activation markers to detect neonatal infection. Clin Exp Immunol 135: 125-129, 2004.

33. Böhler T, Walcher J, Hölzl-Wenig G, Schnitzler P, Geiss M, Buchholz B, Linde R, Rütschle H and Debatin K-M: Expression of CD69 on T-cells from HIV-1-infected children and adolescents increases with increasing viral load. Eur J Pediatr 158: 638-644, 1999

34. Iwashiro M, Messer RJ, Peterson KE, Stromnes IM, Sugie T and Hasenkrug KJ: Immunosuppression by $\mathrm{CD}^{+}{ }^{+}$regulatory $\mathrm{T}$ cells induced by chronic retroviral infection. Proc Natl Acad Sci USA 98: 9226-9230, 2001

35. Vega-Ramos J, Alari-Pahissa E, Valle JD, Carrasco-Marín E, Esplugues E, Borràs M, Martínez-A C and Lauzurica P: CD69 limits early inflammatory diseases associated with immune response to Listeria monocytogenes infection. Immunol Cell Biol 88: 707-715, 2010.

36. Esplugues E, Sancho D, Vega-Ramos J, Martínez C, Syrbe U, Hamann A, Engel P, Sánchez-Madrid F and Lauzurica P: Enhanced antitumor immunity in mice deficient in CD69. J Exp Med 197: 1093-1106, 2003.

37. Sancho D, Gómez M, Viedma F, Esplugues E, Gordón-Alonso M, García-López MA, de la Fuente H, Martínez-A C, Lauzurica P and Sánchez-Madrid F: CD69 downregulates autoimmune reactivity through active transforming growth factor- $\beta$ production in collagen-induced arthritis. J Clin Invest 112: 872-882, 2003.

38. Zhao Q, Kuang D-M, Wu Y, Xiao X, Li X-F, Li T-J and Zheng L: Activated $\mathrm{CD}^{2} 9^{+} \mathrm{T}$ cells foster immune privilege by regulating IDO expression in tumor-associated macrophages. J Immunol 188: 1117-1124, 2012. 